\title{
Phoretic ASSOCIATION OF MITES AND MALlOPHAGA WITH THE PIGEON FLY PSEUDOLYNCHIA CANARIENSIS
}

\author{
MACCHIONI F.*, MAGI M.*, MANCIANTI F.* \& PERRUCCI S.*
}

\section{Summary :}

Myialges anchora Trovessart, 1906 and M. lophortyx (Furman \& Tarshis, 1953) gravid females, surrounded by clusters of eggs, were found strongly inserted into the cuticle of head, thorax, abdomen, femurs and wings of Pseudolynchia canariensis (Macquart, 1840), a hippoboscid fly parasite of the pigeon. This lousefly results obligatory host for ovigerous females of Myialges and for the development of their eggs, and phoretic host because the dispersal of hatching larvae to new hosts may then occur with dispersal of fly carriers. Together with the Myialges species, not ovigerous females of Ornithocheyletia hallae Smiley, 1970 and Columbicola columbae (Linnaeus, 1758) were found on the pigeon fly.

KEY WORDS : Pseudolynchia canariensis, Myialges anchora, M. lophortyx, Ornithocheyletia hallae, Columbicola columbae, pigeon, phoresy.
Résumé : AsSOCIATION PHORÉTIQUE D'ACARIENS ET DE MALLOPHAGES AVEC la MOUCHE PARASITE DU PIGEON, PSEUDOLYNCHIA CANARIENSIS Des femelles gravides de Myialges anchora Trovessart, 1906 et de M. lophortyx (Furman et Tarshis, 1953), entourées de leurs œuffs accolés, ont été trouvées fixées solidement sur la tête, le thorax, l'abdomen, les cuisses et les ailes de Pseudolynchia canariensis (Macquart, 1840), une mouche parasite du pigeon. Ces mouches sont des hôtes obligatoires pour les femelles ovigères des Myalges et pour le développement de leurs œufs, et sont des hôtes phorétiques parce que la dispersion des larves à un nouvel hôte peut se produire avec la dispersion des mouches porteuses. Avec ces espèces de Myalges, ont été trouvées sur la mouche du pigeon des femelles non ovigères d'Ornithocheyletia hallae Smiley, 1970 et de Columbicula columbae (Linnaeus, 1758).

MOTS CLÉS : Pseudolynchia canariensis, Myialges anchora, M. lophortyx, Ornithocheyletia hallae, Columbicola columbae, pigeon, phorésie.
1 seudolynchia canariensis (Macquart, 1840), a hippoboscid fly responsible for the transmission of a pathogenic protozoan, Haemoproteus columbae, moves through the feathers of pigeons, especially young nestling animals 2-3 weeks old, provoking painful wounds during the blood meal.

P. canariensis, parasite of the pigeon, may be infested, in its turn, by mites of the family Epidermoptidae and Cheyletiellidae. Epidermoptidae collected from P. canariensis are: Myialges anchora, $M$. falconis, $M$. lophortyx and M. macdonaldi (Philips \& Fain, 1991; Feres \& Fletchmann, 1991); the presence of Cheyletiellidae on P. canariensis of the pigeon was reported by Feres \& Fletchmann (1991), which found Ornithocheyletia hallae. Jovani et al. (2001) found Epidermoptidae and Cheyletiellidae on P. canariensis, but did not indicate the involved species.

The objectives of this research were to identify arthropods possibly present on $P$. canariensis and to determine the relationship between these organisms and the pigeon lousefly.

\footnotetext{
* Dipartimento di Patologia animale, Università di Pisa, Viale delle Piagge 2, 56124 Pisa, Italy.

Correspondence: Macchioni Fabio.

Tel: ++39-050-570032 - Fax: ++39-050-540644.

E-mail: fmacchion@vet.unipi.it
}

\section{MATERIALS AND METHODS}

5 specimens of $P$. canariensis from pigeons, preserved in $70 \%$ isopropyl alcohol in a collection of the University of Pisa (Department of Animal Pathology), were examined with a binocular dissecting microscope to find phoretic arthropods. Mites and mallophaga were removed, mounted on slides using Hoyer's medium and identified using a phase-contrast microscope.

\section{RESULTS}

1 out of 95 pigeon louse-flies (54\%) presented mites, mostly surrounded by clusters of eggs, strongly inserted into the cuticle of the head, thorax, abdomen, femurs and wings (Fig. 1); mallophaga were also found on one louse-fly. 75 removed mites were identified as females of Myialges lophortyx (Furman \& Tarshis, 1953) (21 ovigerous and five not ovigerous), M. anchora (Trouessart, 1906) (34 ovigerous and six not ovigerous), Ornithocheyletia hallae Smiley, 1970 (nine not ovigerous). Mallophaga were represented by two females of Columbicola columbae (Linnaeus, 1758). 


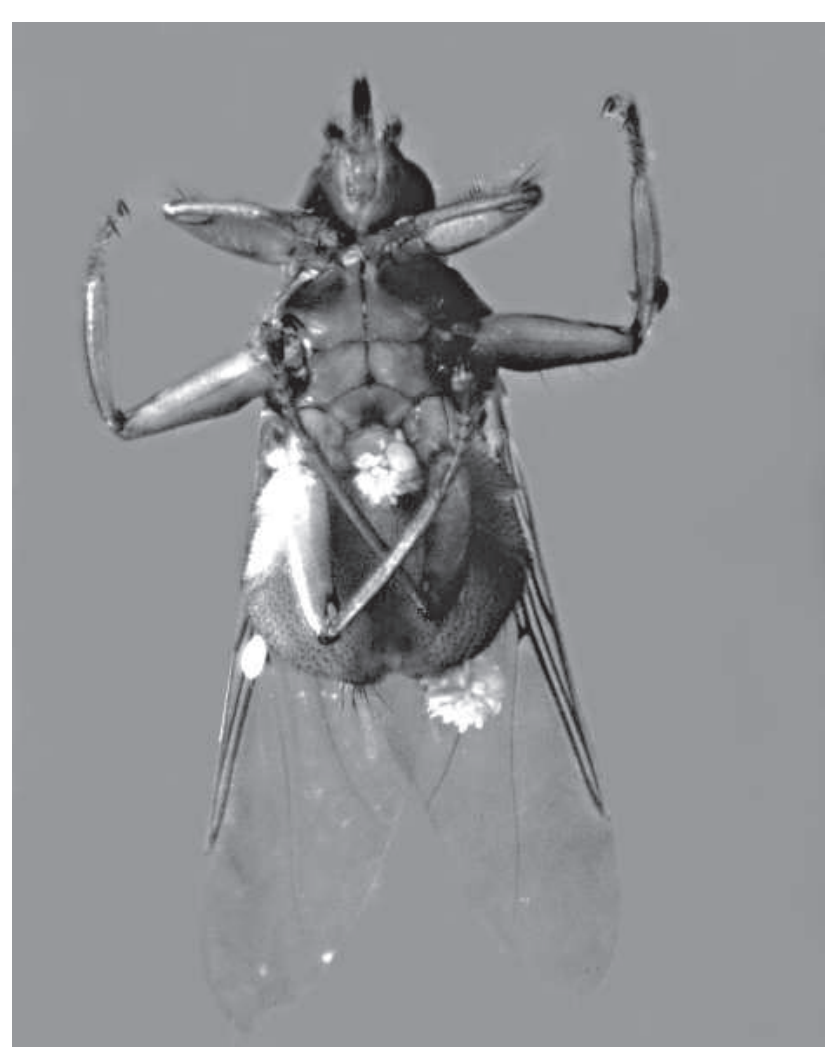

Fig. 1 - Ventral view of Pseudolynchia canariensis with mites and eggs $(\times 8)$.

\section{DISCUSSION}

F arish \& Axtell (1971) defined phoresy as a phenomenon in which one animal actively seeks out and attaches to the outer surface of another animal for a limited time during, which the attached animal (termed the phoretic) ceases both feeding and ontogenesis. Such attachment presumably resulting in dispersal from areas unsuited for further development, either of the individual or its progeny. Activity commences again beginning with detachment, induced by stimuli originating from other its carrier or the microhabitat (Athias-Binche, 1990). The suitable traits of phoresy may be segregated as follow (AthiasBinche, 1991): initiation of phoretic behaviour, active host seeking, recognition of attachment to host surface, quiescence, recognition of signals to disembark and, if needed, synchronization with the host' life cycle.

The phoretic attachment is common in the Acarina and generally occurs on insect hosts like fleas (Fain \& Beaucournu, 1973; Britt \& Molyneux, 1983), mallophaga (Fain, 1965), tse-tse flies (Fain \& Elsen, 1972), domestic flies (Farish \& Axtell, 1971; Ho, 1990), but especially hippoboscid flies ( Fain, 1965; Hill et al., 1967; Walter, 1989; Philips \& Fain, 1991; Jovani et al., 2001).
The feather mite superfamilies include a large number of species which are permanent ectosymbionts of birds, living mainly on the feather surface or in the feather calmus: in the analgoids, which represent most of the feather mites, members of Epidermoptidae are normally encountered in the skin of birds (Fain, 1965). In this family, Myialges mites perform most of their development in the skin of birds; the remaining part of the cycle is completed obligatorily on hippoboscid flies (Fain \& Grootaert, 1996). The life cycle of these mites is known for Myialges macdonaldi, discovered on Parus coeruleus and Leiothrix lutea (Evans et al., 1963). Larvae, nymphs, males and not ovigerous females of this species were mostly present in tunnels burrowed by the mites into the skin of the birds. Ovigerous females, not found on the hosts, were present, surrounded by clusters of their eggs, attached to Hippoboscidae living on birds. These observations show that the deposition of eggs occurs exclusively on flies and we can consider flies obligatory hosts for gravid females laying eggs, and phoretic hosts because the dispersal of hatching larvae to new hosts may then occurs with dispersal of the fly carriers.

While most cheyletids are considered to be free-living predators, some species are associated with other animals in various ways; the family Cheyletiellidae, for instance, includes mites which are parasitic on birds and small mammals (Krantz, 1978). Ornithocheyletia hallae females, members of this family, found on P. canariensis, were not ovigerous; consequently, it is not possible to know if their life cycle is similar to that of Myialges species, and if their presence on hippoboscid flies is connected with dispersal strategies or is simply casual.

The presence of skin mites (Epidermoptidae and Cheyletiellidae) on P. canariensis, and the absence of feather mites, often quite abundant on the pigeon (Falculifer rostratus, Megninia bifida, Pterophagus strictus, according to personal observations), support the observations of Jovani et al. (2001), which found high prevalence and abundance of feather mites on pigeons and their absence on hippoboscid flies, on which many skin mites were detected. According to Philips \& Fain (1991), since feather mites are generally highly host specific while louse flies are not, a phoretic feather mite does not stand a very high chance of a polyxenous fly happening to pick the same host again. Instead, skin mites are more generalist in the use of bird hosts; thus the mites can take advantage of whatever avian their fly host brings them to. Jovani et al. (2001) offer another alternative explanation derived from the location of these mites on the host and the feeding behaviour of louseflies; louseflies feed on blood by piercing the skin of birds and therefore mites living on the skin may have more opportunities to crawl to louseflies than feather mites. More simply, we 
think that another possible explanation may be offered by the very effective attaching structures present in skin mites (ambulacral and/or palpal claws and hooks), generally absent in feather mites.

The presence of C. columbae on $P$. canariensis is interesting because, according to Seguy (1950), phoresy is unusual for Mallophaga and it may be produced by unknown reactions provoking the escape of the insect or phoresy can become obligatory when the host is sick or dies. The scarce presence of specimens on the examined louseflies, when it is known that this chewing louse is frequent and numerous on the pigeon, lead us to think that phoresy in C. columbae is probably accidental.

\section{REFERENCES}

Athias-Binche F. Sur le concept de symbiose. L'exemple de la phorésie chez les acariens et son évolution vers le parasitisme ou le mutualisme. Bulletin de la Société Zoologique de France, 1990, 115, 77-98.

Athias-Binche F. Evolutionary ecology of dispersal in mites. Ecology and evolution of phoresy in mites. In: Modern Acarology. F. Dusbabek \& V. Bukva, (eds.), SPB, The Hague/Academia, Praha, 1991, 27-41.

BRITT D.P. \& Molyneux D.H. Phoretic associations between hipopi of Acarus nidicolous (Acari, Astigmata, Acaridae) and fleas of british small mammals. Annales de Parasitolologie Hummaine et Comparée, 1983, 58, 95-98.

Evans G.O., Fain A. \& Bafort J. Découverte du cycle évolutif du genre Myialges avec description d'une espèce nouvelle (Myialgidae: Sarcoptiformes). Bulletin et Annales de la Société Royale d'Entomologie de Belgique, 1963, 99, 486-500.

FAIN A. A review of the family Epidermoptidae Trouessart parasitic on the skin of birds (Acarina: Sarcoptiformes). Konink VI Acad. Wetensch. Let. Schone Kunst. Belg. 1965, 84 (I-II), 1-176, 1-144.

Fain A. \& Beaucournu J.C. Two new hypopi living in phoretic association on the fleas of carnivora (Acarina: Sarcoptiformes). Acarologia, 1973, 15, 138-143.

FAIN A. \& Elsen P. Notes sur les acariens parasites ou commensaux des mouches tsé-tsé. 1. Familles Saproglyphidae et Anoetidae (Sarcoptiformes). Acta Zoollogica et Pathologica Antverpoenna, 1972, 55, 71-90.

FaIN A. \& Grootaert P. Observations sur des Acariens (Acari: Epidermoptidae) parasites d'Ornithomyia avicularia (L.) (Diptera: Hippoboscidae). Bulletin et Annales de la Société Royale d'Entomologie de Belgique, 1996, 132, 183-186.

FARISH J.D. \& AXTELL R.C. Phoresy redefined and examined in Macrocheles muscaedomesticae (Acarina: Macrocheilidae). Acarologia, 1971, 13, 16-28.

FERES R.J.F. \& Flechtmann C.H.W. Ocorrencia de acaros "parasitos-foréticos" (Acari: Epidermoptidae, Cheyletiellidae) sobre moscas hipoboscideas de pombo, em Sao José do Rio Preto. Naturalia, Sao Paulo, 1991, 16, 155-160.
FuRMAN D.P. \& TARSHIS I.B. Mites of the genera Myialges and Microlichus (Acarins: Epidermoptidae) from avian and insect hosts. Journal of Parasitology, 1953, 93, 70-78.

Hill D.S., Wilson N. \& Corbet G.B. Mites associated with British species of Ornithomya (Diptera: Hippoboscidae). Journal of Medical Entomology, 1967, 4, 102-122

Jovani R., Tella J.L., Sol D. \& Ventura D. Are hippoboscid flies a major mode of transmission of feather mites? Journal of Parasitology, 2001, 87, 1187-1189.

Krantz G.W. A manual of Acarology, II ed. (emended 1986). Oregon State University Book Stores, Corvallis, 1978, 509 p.

Philips J.R. \& FAIN A. Acarine symbionts louseflies (Diptera: Hippoboscidae). Acarologia, 1991, 32, 377-384.

SEgur E. Phorésie et rôle pathogène chez les diptères. Eos. Revista Espanola de Entomologia Tomo extraordinario, 1950, 315-317.

SMiLEy R.L. A review of the family Cheyletiellidae (Acarina). Annals of the Entomological Society of America, 1970, 63, 1056-1078.

WALTER G. Phoresy and hyperparasitism in Ornithomya (Diptera, Hippoboscidae) in the Federal Republic of Germany. Angewandte Parasitologie, 1989, 30, 43-46.

Reçu le 23 avril 2004 Accepté le 6 avril 2005 